Ankara Üniversitesi

SBF Dergisi,

Cilt 66, No. 4, 2011, s. 21-31

\title{
AGE, EMPLOYMENT AND EDUCATIONAL REFORM: AN ALTERNATIVE VIEW OF UNEMPLOYMENT IN TURKEY
}

\author{
Dr. Nevin Çavuşoğlu \\ James Madison University \\ Economics College of Business
}

\author{
Philip Heap \\ James Madison University \\ Economics College of Business
}

\author{
Dr. Robert Horn \\ James Madison University \\ Economics College of Business
}

\begin{abstract}
Unemployment rates reported by governmental authorities do not account for changes in the age and sex composition of the labor force. However, different age groups tend to have different unemployment rates, and changes in the relative importance of these groups in the labor force will affect measures of unemployment. We apply an alternative age-adjusted unemployment rate to Turkey between 1988 and 2009, and find that if the relative composition of the labor force had not changed, the reported unemployment rate would have been as much as $10.7 \%$ higher in 2007 . The main factor that has led to the lower reported unemployment rates has been the fall in the labor force participation of men and women aged 15-24. We argue that the main reasons for this change in the relative age composition of the labor force are new education laws, which have kept younger workers out of the labor force.
\end{abstract}

Keywords: Unemployment, labor force, age, schooling, education reform Bakıs

Yaş, İstihdam ve Ĕgitim Reformları: Türkiye İsssizlik Oranına Alternatif

\section{Özet}

Devlet tarafından hesaplanan işsizlik oranları işgücündeki yaş ve cinsiyet değisikliklerini dikkate almamaktadir. Fakat değisik yaştaki çalisanların işsizlik oranları farklı olduğundan, bu grupların işgücündeki göreceli oranlarının değişmesi işsizlik oranını etkileyecektir. Bu yazıda Türkiye ile ilgili olarak 1988 ve 2009 yılları arası için işgücünün yaş bileşimindeki değişikliklerini dikkate alan alternatif bir işsizlik oranı geliştiriyoruz. Bu alternatif işsizlik oranına gore eğer işgücünün yaş bileşiminde değişiklik olmasaydı 2007 yılının işsizlik oranı rapor edilenden $10.7 \%$ daha yüksek olurdu. Veriler rapor edilen işsizlik oranının düşük olmasının başlıca nedeninin 15-24 yaş arası kadın ve erkeklerin işgücündeki oranlarının düşmesinden kaynaklandığına işaret etmektedir. İşgücünün yaş bileşimindeki bu değişikliğin ana nedeninin eğitim alanındaki kanun değişiklikleri olduğunu öne sürmekteyiz. Yeni eğitim kanunları genç işçilerin işgücündeki payını azaltmıştır.

Anahtar Sözcükler: İşsizlik, işgücü, yaş, okullaşma, eğitim reformu 
- Ankara Üniversitesi SBF Dergisi • 66-4

\section{Age, Employment and Educational Reform: An Alternative View of Unemployment in Turkey}

\section{Introduction}

The unemployment rate is widely considered one of the most important indicators of economic activity and an important measure of the "health" of an economy. Indeed, politicians and pundits of every political persuasion eagerly await new employment statistics, which they then use to "demonstrate" the success or failure of current economic policy. However, the reported unemployment rate does not differentiate among full time and involuntary part time workers, discouraged workers, laborers trapped in jobs below their appropriate skill level and so forth. Furthermore, the reported unemployment rate does not take into account the fact that the age and sex composition of the labor force changes over time. Horn (1988) and Horn and Heap (1999) argue that since unemployment rates vary by age and by sex, changes in the relative importance of these groups in the labor force affect comparisons of unemployment over time.

Horn and Heap (1999) develop an alternative measure, called the ageadjusted unemployment rate, which controls for changes in the age and sex composition of the labor force by weighting the unemployment rate according to the respective sex and age share of the labor force in a base year. They conclude that between 1970 and 1997 the reported United State's unemployment rate would have been 0.4 to 0.5 percentage points higher if the age composition of the labor force had not changed.

Rosnik (2010) and Szafran (2006) perform an analysis similar to Horn and Heap (1999) for the United States. Rosnik (2010) finds that the ageadjusted unemployment rate during the recent recession was higher and stayed above $10 \%$ for longer compared to the age-adjusted unemployment rate during 
the downturn of the early 1980s. The reported unemployment rate, in contrast, suggests that the labor market was weaker in the early 1980s compared to the recent recession. Szafran (2006) reports that states with a higher share of older individuals (over 65 years of age) in their population experience lower unemployment for these older individuals.

In this paper, we apply the alternative age-adjusted unemployment measure developed in Horn (1988) to Turkey between 1988 and 2009. We find that had the relative composition of the labor force not changed within this period, the reported unemployment rate would have been as much as $10.7 \%$ higher in 2007 (9.3\% higher in 2009), leading to an additional 262,564 unemployed workers $(379,619$ in 2009).

The unemployment rate in Turkey has been especially high after 2002 with the reported unemployment rate being persistently higher than $10 \%$. As stated in Ceylan-Ataman (2006), Turkey has experienced a jobless recovery from the crisis of 2001: even the high level of growth rates after 2002 have only slightly helped with the unemployment problem. Our analysis shows that the two major education reform laws enacted in Turkey in 1997 and 2001 have helped lower the unemployment rate by changing the age composition of the labor force. As stated in the OECD (2010) report, these education reforms are a good start for improving education attainment and quality to equip the future labor force with better skills. ${ }^{1}$

We discuss the age-adjusted unemployment in more detail in the next section. Then we discuss changes in education laws and their impact on schooling ratios. The last section summarizes our findings and concludes.

\section{The Age-Adjusted Unemployment Rate}

Changes in the age and sex composition of the labor force affect the reported unemployment rate because different age groups tend to have different rates of unemployment. Young workers, in Turkey, have consistently higher unemployment rates than older workers. Between 1988 and 2009, for example, the average unemployment rate for men and women in Turkey aged 15-24 was $17.2 \%$ as opposed to $6.8 \%$ for the age cohort of $25-54$ and only $2.5 \%$ for the

\footnotetext{
${ }^{1}$ The model of labor force participation, employment and education is well founded in economics. Becker (1975: 38-40) is among the first American economists to argue that higher level of human capital leads to higher labor force participation and earnings.
} 
age cohort of 55-64. ${ }^{2}$ Therefore, when the labor force participation of younger workers declines (increases), the reported unemployment rates tend to fall (rise) since groups, which historically have higher than average unemployment rates, comprise a smaller (larger) share of the work force.

Data by age groups reveal that over the period considered, the labor force participation of men and women aged 15-24 declined, while participation by men and women aged 25-54 increased. ${ }^{3}$ Due to the different unemployment rates of these age groups, these developments would naturally lead to a lower reported unemployment rate, ceteris paribus. This implies that the reported unemployment rate, which does not take this shift in the age composition of the labor force into account, will tend to appear lower.

To capture these effects, we calculate the adjusted unemployment rate $\mathrm{u}^{*}$ in year $\mathrm{t}$, as follows:

$$
\mathrm{u}_{\mathrm{t}}{ }^{*}=\sum_{i} \mathrm{LF}_{\mathrm{i}} \mathrm{u}_{\mathrm{it}},
$$

where $L F_{i}$ is the labor force share of group $i$ in the base year, and $u_{i t}$ is the unemployment rate of group $i$ in year $t$. The age-adjusted unemployment rates constructed here use 1980 as the base year. The age-adjusted unemployment rate provides a description of what the Turkish unemployment rate would have been had the age and gender composition of the work force remained as it was in the base year.

\footnotetext{
${ }^{2}$ The unemployment rate for men is usually only slightly higher than the unemployment rate for women for the groups aged 15-24 and 25-54. The difference for the group aged $55-64$ is large: $4.2 \%$ for men versus $0.8 \%$ for women.

${ }^{3}$ Participation of men (women) aged 15-24 has decreased from 18\% (11\%) to $13 \%$ $(6 \%)$, and the participation of men (women) aged 25-54 has increased from $44 \%$ $(16 \%)$ to $55 \%(17 \%)$.
} 
Table 1: Reported and Age-Adjusted Unemployment Rates

\begin{tabular}{|c|c|c|c|}
\hline Year & Reported & Adjusted & Difference \\
\hline 1988 & 8.44 & 8.44 & 0.00 \\
1989 & 8.59 & 8.77 & 0.18 \\
1990 & 8.01 & 8.21 & 0.20 \\
1991 & 8.21 & 8.10 & -0.11 \\
1992 & 8.51 & 8.46 & -0.05 \\
1993 & 8.96 & 8.99 & 0.03 \\
1994 & 8.58 & 8.58 & 0.01 \\
1995 & 7.64 & 7.84 & 0.20 \\
1996 & 6.63 & 6.80 & 0.17 \\
1997 & 6.84 & 7.13 & 0.29 \\
1998 & 6.89 & 7.25 & 0.36 \\
1999 & 7.69 & 8.07 & 0.38 \\
2000 & 6.49 & 6.92 & 0.42 \\
2001 & 8.38 & 8.91 & 0.53 \\
2002 & 10.36 & 11.07 & 0.72 \\
2003 & 10.54 & 11.51 & 0.97 \\
2004 & 10.84 & 11.75 & 0.91 \\
2005 & 10.64 & 11.55 & 0.91 \\
2006 & 10.24 & 11.19 & 0.95 \\
2007 & 10.28 & 11.36 & 1.08 \\
2008 & 10.97 & 12.07 & 1.10 \\
2009 & 14.03 & 15.34 & 1.31 \\
\hline
\end{tabular}

Source: The raw data used to calculate both the reported and adjusted unemployment rates were obtained from the OECD Labour Market Statistics Database.

A comparison of the reported and age-adjusted unemployment rates, reported in Table 1 and Figure 1, reveals that the age-adjusted unemployment rate has been consistently higher than the reported unemployment rate after 1995 and even more so starting in 1997. The difference has been rising almost continuously since 1996 , from $0.17 \%$ to $1.31 \%$ in 2009 . This implies that had there been no changes in the age composition of the labor force in 2009 , the unemployment rate would have been $15.3 \%$, about $9 \%$ higher than the reported $14 \%$. The difference between the adjusted and reported unemployment rates is largest for $2007: 11.4 \%$ and $10.3 \%$, respectively, which amounts to a $10.7 \%$ difference. 
- Ankara Üniversitesi SBF Dergisi • 66-4

Figure 1: Difference Between Age-Adjusted and Reported Unemployment Rates

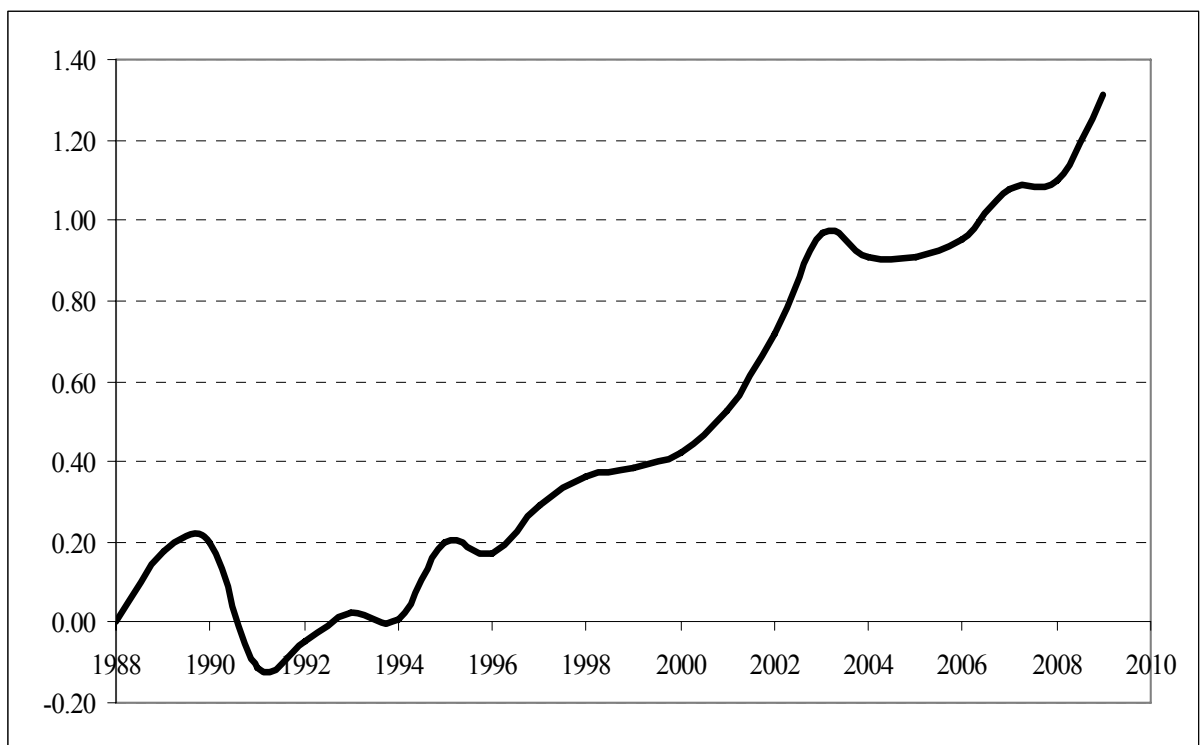

Source: See source for Table 1.

Given that a change in the age composition of the labor force can have such a large impact on the unemployment rate, it is natural to wonder what would cause such a change. We contend that the two major education reform laws enacted in Turkey during this time period go a long way in explaining the widening gap between the reported and age-adjusted unemployment rates. In the next section, we provide an account of these policy changes and show the impacts of education reforms on the age structure of the labor force.

\section{Schooling Ratios}

The schooling ratios (enrolled relative to population) at different levels of education have clearly changed with the education laws passed in 1997 and $2001 .{ }^{4}$ Education Law 4306, passed in August 1997, increased compulsory education from five to eight years starting with the 1997-1998 school year. Since then, the gross (net) schooling ratio for primary education increased

${ }^{4}$ Data on schooling ratios comes from the Turkish Statistical Institute. 
steadily from $85 \%(77 \%)$ to $101 \%(95 \%)$ in $2001-2002$ (see Figure 2$).{ }^{5}$ This increase in the primary schooling ratio corresponds to the first wave of the significant increase in the difference between the reported and the age-adjusted unemployment rates, as shown in Figure 1. Part of this increasing difference is possibly due to the fact that some men and women aged 15-24 either quit the labor force or, more likely, delayed their entry into the workforce in order to fulfill the additional three years of compulsory education. This would be the case due to the indirect effect the law will have on these workers due to the preference of employers to hire workers in the same age-group that have completed the required years of education. One must also mention that the causality could also work in the other way, i.e. it is possible that individuals that were unemployed went back to school to complete the required years of education. ${ }^{6}$

Figure 2: Gross and Net Primary Education Schooling Ratios

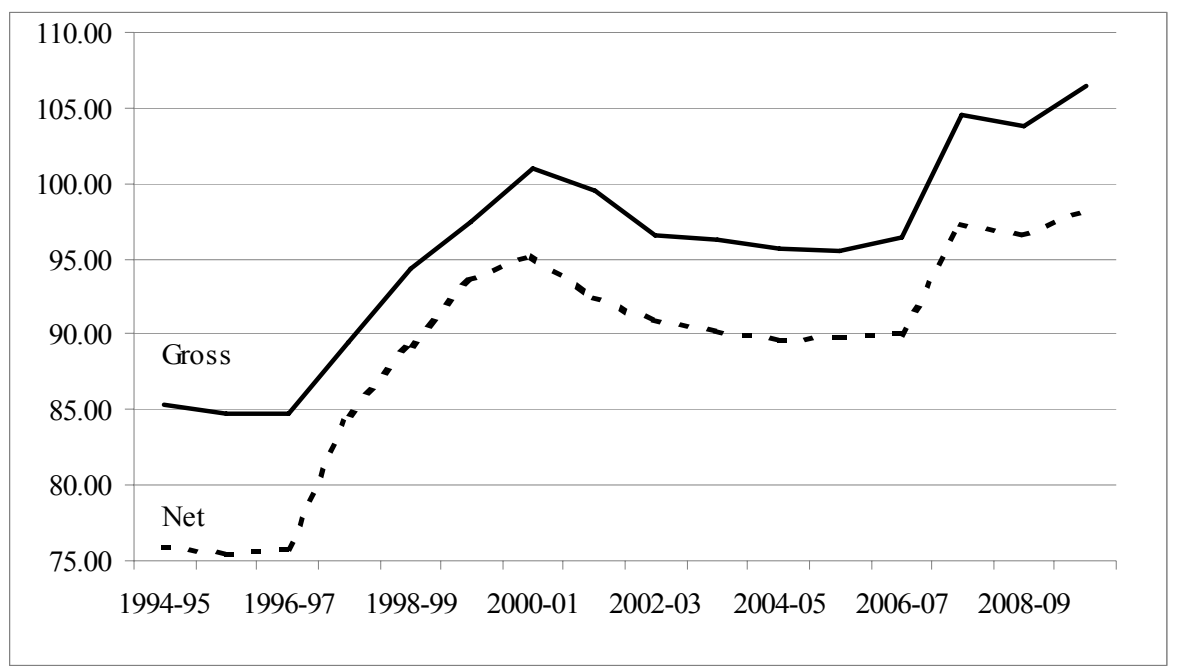

Source: Turkish Statistical Institute.

${ }^{5}$ Gross primary schooling refers to the number of all students enrolled in primary school as a share of the total number of primary school age students and thus it can be higher than $100 \%$. Net primary schooling is the share of students of the official primary school age only.

${ }^{6}$ One should note that the labor force participation of men aged 25-54 has an upward trend for the whole sample and that Education Law 4306 would be only part of the explanation for this trend. The upward trend for women aged 25-54 clearly starts after 1997. 
In July 2001 Education Law 4702 passed. It allowed vocational and technical high school graduates to enroll in two-year higher education programs without taking the university entrance examination. This law had a positive effect on both secondary and higher education schooling ratios. Young individuals might have become more inclined to choose vocational and technical high schools for their secondary education. In addition, a larger number of vocational and technical high school graduates are likely to continue with two-year higher education. Data on vocational and technical high school students start in 1999-2000, but they show a steady increase in enrollment ratios starting with the 2002-2003 school year. Gross and net schooling ratios on secondary education, which include vocational and technical high schools, have been rising since 1998-1999, but show two big jumps in 2001-2002 and 2002-2003 (see Figure 3). Gross and net schooling ratios on higher education have steadily increased starting with school year 2000-2001 (see Figure 4). These data indicate that the law caused some young individuals to withdraw from the labor force or delay entering the labor force to continue their education.

Figure 3: Gross and Net Secondary Education Schooling Ratios

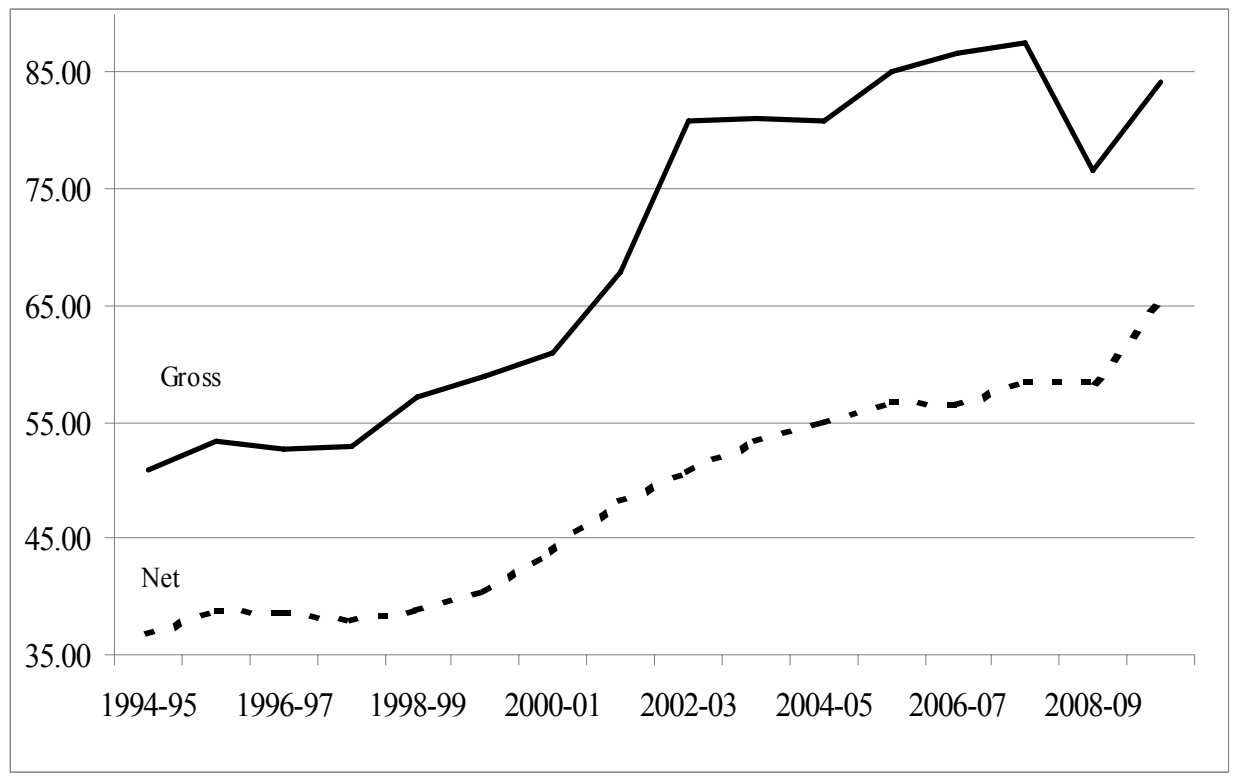

Source: Turkish Statistical Institute. 
In addition to these changes in education laws, the education trend of the population in general is also likely to play a role in one's decision on how much education to get. A more educated population in general leaves young people with little choice but getting more education themselves. ${ }^{7}$ This could explain the increase in general secondary schooling ratios and as well as the increase in schooling ratios at all education levels. In fact, between 2001 and 2009 , the number of institutions for secondary education increased from 6,367 to 8,913 , and the number of vocational and technical high schools increased from 3,732 to $4,846 .{ }^{8}$ The number of universities increased from 76 in 2002 to 83 in 2006 and 139 in $2009 .{ }^{9}$ For the same time period the number of students as a share of the total population has increased. ${ }^{10}$ Thus, this rise in the number of education institutions reflects higher demand for education in excess of the growth in the population.

Figure 4: Gross and Net Higher Educations Schooling Ratios and Gross Enrollment in Tertiary Education

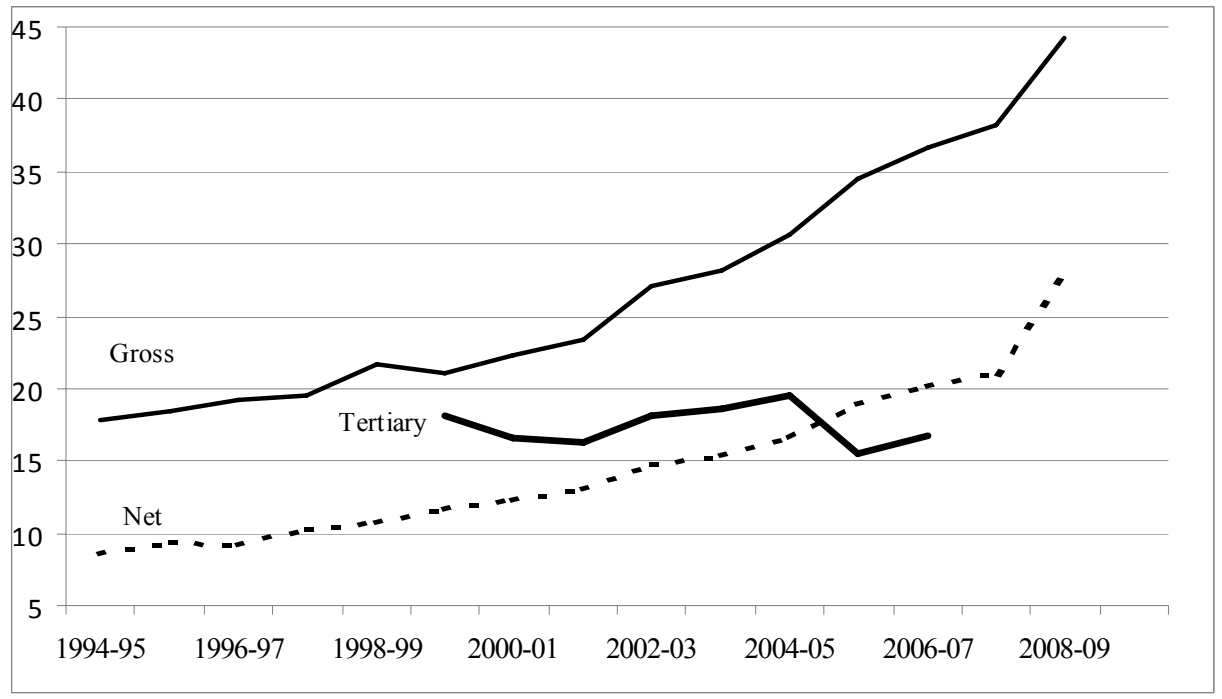

Source: Turkish Statistical Institute.

${ }^{7}$ For a discussion of education as a "human capital externality" see Borjas (2010: 347349).

${ }^{8}$ Turkish Statistical Institute.

${ }^{9} \mathrm{http}: / /$ www.nethaber.com/Ekonomi/107968/Turkiyedeki-universite-sayisi-139a-cikti

${ }^{10}$ Turkish Statistical Institute. 


\section{Conclusion}

In sum, the two education laws combined with the general trend of more years of education in the population overall has led to a higher demand for education by the young population. This has affected the labor market, and has led to a lower share of young individuals in the labor force. Since the unemployment rate is historically highest for young individuals, such a fall in their labor force share would naturally lead to a lower unemployment rate compared to the unemployment rate one would report if there was no change in the age structure of the labor force. More specifically, had the age structure of the labor force not changed the number of unemployed individuals in 2009 would have been 379,619 higher than reported. Turkish officials should be glad the education reforms lowered the labor force participation of those most prone to high unemployment.

Often, economists are quick to argue in favor of some type of fiscal or monetary stimulus to get a sluggish economy moving. While Turkey's unemployment rate remains high relative to most European countries, adopting structural reforms seemed to be an effective way to move a high unemployment group out of the labor force. Although the intent of the education laws is to increase the education level of the population, the laws have indirectly lowered unemployment rates. ${ }^{11}$ Thus, the country gains from such policies not only via increased productivity but also via lower unemployment rates as these newly educated workers move into the labor force at ages and experience levels where they will not be as prone to unemployment.

\footnotetext{
${ }^{11}$ UNESCO.
} 


\section{References}

Becker, Gary (1975), Human Capital, $2^{\text {nd }}$ edition, New York: Columbia University Press.

Borjas, George J. (2010), Labor Economics, $5^{\text {th }}$ edition, Boston: McGraw Hill IRWIN.

Ceylan-Ataman, B. (2006), "Türkiye'de 2000-2005 Dönemi İşsizlik Üzerine Tartışmalar”, Iktisat, Isletme ve Finans, 21 (239): 93-107.

Horn, Robert N. (1988), "An Age-Adjusted Unemployment Rate”, Challenge, July-August: 56-58.

Horn, Robert and Philip Heap (1999), "The Age-Adjusted Unemployment Rate: An Alternative Measure”, Challenge, January-February: 110-115.

OECD Economic Surveys: Turkey, September 2010.

OECD Labour Market Statistics Database, http://stats.oecd.org/index.aspx.

Rosnik, David (2010), "The Adult Recession: Age-Adjusted Unemployment and Post-War Highs", Center for Economic and Policy Research, July: 1-4.

Szafran, Robert F. (2006), "The Effect of Age Group Growth on Labor Force Participation: The Case of Older Workers", mimeo.

Turkish Statistical Institute, National Education Statistics, Formal Education 2009-2010. http://www.tuik.gov.tr/PrelstatistikTablo.do?istab_id=135

UNESCO International Bureau of Education, World Data on Education, $6^{\text {th }}$ edition http://www.ibe.unesco.org/fileadmin/user_upload/archive/Countries/WDE/2006/CENTRA L_and_EASTERN_EUROPE/Turkey/Turkey.htm 